\title{
DESENTRALISASI FISKAL KONTEMPORER DALAM PERSPEKTIF KEBIJAKAN PUBLIK ISLAM
}

\author{
Any Setianingrum \\ Fakultas Ekonomi Universitas Az Zahra Jakarta \\ E-mail: anysetianingrum@yahoo.com
}

\begin{abstract}
One of the essential instruments designed for achieving the goals of sharia in Islam is fiscal policy. There are some key elements of Islamic fiscal theory, namely: 1) Islamic Economics, which comprises private sector, social/ voluntary sector, and public sector. The collaboration of these three sectors would provide an ideal Islamic economic institutional framework; 2) Zakat (taxation of income and wealth of a Muslim) as the basis of fiscal system; 3) Implementation of all fiscal instruments which disallow exploitation that results in usury (riba), uncertainty (gharar), speculation, sinful (haram) products / services and all forms of meanness. 4) Allocation, distribution and stabilization functions of Islamic economics is administered and presented through all the sectors cooperatively; 5) Public sector does not affect significantly yet essential on condition that it works continuously to ensure optimum allocation of society resources, income distribution, and stability establishing.
\end{abstract}

Keywords: Fiscal Decentralization, Islamic FiscalPolicy, Zakat, Allocation, Distribution, Stabilization.

\begin{abstract}
Abstrak
Kebijakan fiskal dalam islam merupakan salah satu alat yang bekerja untuk mencapai tujuan Syariah. Unsur-unsur utamadariteori fiskal Islam iniadalah: 1) Ekonomi Islamterdiri dari ekonomitigasektor, yaitu,sektor swasta, sektor sosial/sukarela,dan sektor publik. Tiga sektorbekerja sama, memberikankerangka kelembagaanpada perekonomian Islam; 2) Zakatsebagai dasardari sistemfiskal; 3) Penerapan semua instrumen fiskal melarang adanya eksploitasi yang menyebabkan riba, ghararl ketidakpastian, spekulasi, produk/jasa yang diharamkan dan semua bentuk kezaliman. 4) Alokasi, distribusi danfungsi stabilisasi dariekonomilslamdiprosesdan dilaksanakan melaluisemua sektortersebut secara bersama-sama; 5) Peransektor publikdibanding sektor lain adalahminimal tapipentingsejauhberoperasiterus menerusuntuk memastikanalokasioptimalsumber daya yang ada dalam masyarakat, distribusi pendapatan, dan membangun stabilitas.
\end{abstract}

Kata kunci: Desentralisasi Fiskal, Kebijakan Fiskal Islam, Zakat, Alokasi, Distribusi, Stabilisasi.

Kebijakan fiskalterpusat yang selama ini banyak dijalankan oleh pemerintah pusat di banyak negara di dunia telah banyak me- nemukan kegagalan dalam berbagai aspek. Kegagalan tersebut banyak menimbulkan kesalahan alokasi sumber daya yang ber- 
akhir pada kegagalan pembangunan ekonomi. Kegagalan ekonomi memilikimultiplier effect yang luas, meliputi ketidakseimbangan dalam bidang sosial, ekonomi, politik, pertahanan dan keamanan suatu negara. Maka selama beberapa dekade terakhir muncul kebijakan desentralisasi fiskal di banyak negara sebagai jawaban atas kegagalan sistemfiskal yang terpusat.

Reformasi sistem ekonomi di berbagai negara selama tahun 1980 terutama difokuskan pada peningkatan peran pasar dan meningkatkan peran lingkungan sumberdaya setempat. Untuk beberapa tahun, ada keasyikan dengan sektor swasta, sehingga reformis hampir melupakan peran potensial sektor publik dalam mempromosikan pembangunan. Dalam beberapa tahun terakhir, telah ada upaya luas baik untuk mendefinisikan kembali peran sektor publik khususnya di negara berkembang dan untuk meningkatkan kinerjanya. Sebuah komponen yang semakin penting dari reformasi ini adalah pengenalan kebijakan untuk mendesentralisasikan fungsi pemerintah. Selama tahun 1990, desentralisasi fiskal dan reformasi pemerintah daerah telah menjadi salah satu tren yang paling luas dalam pembangunan. Mengingat kinerja ini tidak merata keberhasilannya, ada perdebatan luas tentang konsep desentralisasi fiskal dan bagaimana mendekatinya.

Literatur tentang implikasi sosial ekonomi desentralisasi fiskal dewasa ini telah berkembang. Tentu saja ada banyak kendala dan tantangan dalam mewujudkan desentralisasi fiskal yang ideal. Dimana antara 1 negara dengan negara lain tentu memiliki perbedaan model dan metode yang berbeda. Tidak hanya kegagalan pemerintah pusat yang mendorong adanya kebijakan desentralisasi fiskal di banyak negara, namun sekaligus juga didukung adanya fenomena demokrasi dan tuntutan kesejahteraan yang lebih merata dan adil dengan konsep mengoptimalkan keunggulan komparatif pemerintah lokal. Namun apakah desentralisasi fiskal yang dijalankan oleh banyak negara berhasil mempromosikan perekonomian daerah, dan bagaimana tingkat keberhasilan tersebut jika ditinjau dari perspektif kebijakan publik Islam? Masalah yang paling penting dalam menganalisa desentralisasi fiskal adalah kurangnya informasi komparatif baik dugaan manfaat dan kerugian desentralisasi fiskal yang telah terwujud di bebagai negara. Informasi komparatif tersebut akan memimpin jalan untuk pengembangan konseptual yang lebih baik dan kebijakan publik yang lebih efektif.Makalah ini akan menganalisa lebih jauh tentang hal tersebut, yakni menganalisis efektifitas kebijakan desentralisasi fiskal yang diterapkan di berbagai negara terhadap keberhasilan perekonomian negara secara komprehensif dan tinjauan kebijakan publik Islam terhadap efektifitas tersebut.

Desentralisasiyang didefinisikan sebagai devolusi kekuasaan dan wewenang untuk lokal, memilikiaspek politik dan administrasi ekonomi fiskal (Litvack, 1999). Desentralisasi fiskaldapat didefinisikan sebagai pelimpahan tanggung jawab kebijakan dari pemerintah pusat terhadap pemerintah daerah berkaitan dengan keputusan pengeluaran dan pendapatan. Desentralisasi telah dilihat menjadi fitur menarik dari reformasi berdasarkan alasan berikut: 1) Desentralisasi pengeluaran meningkatkan efisiensi ekonomi karena pemerintah daerah memiliki informasi yang lebih baik tentang preferensi lokal, dan karena itu memungkinkan ketentuanyang lebih cocok dengan preferensi warga (Samuelson, 1995); 2) Desentralisasi diharapkan dapat meningkat- 
kan akuntabilitas dan transparansi dalam pemberian layanan (de Mello, 2000); 3) Selain itu, jika akuntabilitas lokal ada, pembayar pajak mungkin juga bisa lebih baik bekerja sama dengan pemerintah daerah (Wasylenko, 2001).

Argumen tersebut, pada gilirannya, menyebabkan kita untuk berhipotesis bahwa desentralisasi dapat menyebabkan defisit anggaran yang lebih rendah dan inflasi yang lebih rendah melalui peningkatan efisiensi sektor publik.

Tanzi (2000) menunjukkan,bahwa efektivitas desentralisasi fiskal tergantung pada faktor-faktor seperti ukuran negara, tingkat privatisasi dalam perekonomian, kemampuan pemerintah daerah untuk meningkatkan pendapatan, transparansi dan kapasitas administrasi dan kelembagaan lokal. Bukti empiris untuk mendukung argumen ini dapat ditemukan di Panizza (1999), yang menunjukkan bahwa semakin besar negara semakin besar keuntungan dari informasi pemerintah daerah, dan Von Braun dan Grote (2000), yang secara empiris menunjukkan bahwa desentralisasi fiskal membantu menghilangkan kemiskinan jika politik desentralisasi didukung dengan pemerintah daerah yang akuntabel.

Terhadap konsep desentralisasi pengeluaran dan pendapatan, dikemukakan dalam berbagai hasil penelitian bahwa, pengeluaran dalam kebijakan anggaran desentralisasi cenderung meningkatkan efisiensi, tidak demikian dengan desentralisasi pendapatan. Beberapa alasan penjelasannya sebagai berikut: 1) Pemerintah daerah sering menghadapi kendala anggaran dari pemerintah pusat; 2) Banyaknya kepentingan yang tidak relevan pada pemerintahan lokal; 3) Keterbatasan sumber pajak bagi pemerintah daerah atau mereka gagal untuk sepenuhnya meman- faatkan yang sudah ada; 4) Selanjutnya, penerbitan utang lokal dan kapasitas pengelolaan terbatas. Untuk alasan ini, pembagian pendapatan vertikal dan horizontal umumnya diperlukan (De Mello, 2000) dan De Mello dan Barenstein[2001]). Dalam sebuah studi dari 69 negara selama periode 1980-1998, De Mello dan Barenstein (2001), misalnya, menunjukkan bahwa, tidak seperti desentralisasi pengeluaran, semakin rendah desentralisasi pendapatan, semakin baik pemerintahan.

Konsekuensi Otonomi pendapatan Terbatas pemerintah daerah tersebut menyiratkan, bagaimanapun, bahwa otonomi pengeluaran mereka juga mungkin terbatas dan dengan demikian pemerintah daerah dapat berubah menjadi unit-unit pembelanjaan hanya dari pemerintah pusat. Hal ini, pada gilirannya, membatasi kemampuan pemerintah daerah untuk melakukan siklus makroekonomi counter di tingkat lokal (De Mello, 2000). Ada juga berbagai argumen terhadap desentralisasipengeluaran, sebagai berikut: 1) Pemerintah daerah dapat meengalami kekurangan skala ekonomi dalam penyediaan barang publik, khususnya, biaya informasi dan koordinasimungkin lebih tinggi bagi pemerintah daerah daripada pemerintah pusat; 2) Jika kepentingan lokal yang kuat, dengan tidak adanya akuntabilitas lokal, desentralisasi meningkatkan korupsi dan fragmentasi sosial(Blanchard dan Shleifer,2000) dan Bradhan dan Mookherjee (1998); 3) Desentralisasi dapat meningkatkan persaingan dan ketegangan politik di antara pemerintah daerah; 4) Kurangnya kapasitas kelembagaan dan administrasi pemerintah daerah dapat mencegah manfaat desentralisasi; 5) Masalah koordinasi antar tingkatan pemerintahan yang berbeda dapat menghambat reformasi fiskal dan pelaksanaan penyesuaian ekonomi makro. 
Dalam pandangan dari berbagai teori menunjukkan bukti adanya pengaruh signifikan dari desentralisasi fiskal, baik yang mendukung maupun yang menemukan bukti desentralisasi fiskal merugikan.

Literatur tentang implikasi sosial ekonomi desentralisasi fiskalbaru-baru ini telah berkembang. Salah satu topiknya adalah penelitian tentang kemungkinan hubungan desentralisasi fiskal, defisit anggaran dan inflasi dengan menggunakan berbagai ukuran pengeluaran dan pendapatan desentralisasi menunjukkan bahwa desentralisasi fiskal secara signifikan berhubungan negatif dengan defisit anggaran dan inflasi. Ada juga bukti yang signifikan bahwa, semakin besar ukuran negara, pemerintahan yang baik dan akuntabilitas lokal memperkuat hubungan antara desentralisasi fiskaldan kinerja ekonomi makro (Duk-yun Hwang, Jun-ho Choi, Young-mi Lee).

Sejumlah penelitian telah menunjukkan bahwa desentralisasi pengeluaran berhubungan positif dengan berbagai indikator sosial. De Mello (2000) melihat 30 negara selama periode 1970 sampai 1995 dan menunjukkan bahwa modal sosial yang lebih tinggi, yang didefinisikan sebagai kepercayaan pada pemerintah, kerjasama sipil dan aktivitas asosiasi, berhubungan positif dengan desentralisasi fiskal, terutama bila diukur oleh ketidakseimbangan vertikal. Dalam sampel panel lebih dari 500 pengamatan, yang mencakup periode 19701995, Robalino et al. (2001) menunjukkan bahwa desentralisasi pengeluaran berhubungan negatif dengan tingkat kematian. Selanjutnya, Von Braun dan Grote (2000) secara empiris menunjukkan, menggunakan data untuk 50 negara, bahwa desentralisasi fiskal membantu untuk menghilangkan kemiskinan. Dalam data cross-section, Treisman (2000), menemukan bukti hubungan negatif antara desentralisasi dan kualitas kesehatan dan pendidikan, sebagai langkah penyediaan pelayanan publik.

Menggunakan data dari kurang lebih 80 negara selama periode 1984-1998, De Mello (2001) menemukan bukti bahwa tata kelola yang baik berhubungan positif dengan tingkat pengeluaran subnasional dan semakin tinggi pendapatan non-pajak (yaitu hibah dan transfer dari pemerintah yang lebih tinggi). Selain itu, Fisman dan Gatti (2002) menemukan hubungan negatif yang kuat antara desentralisasi pengeluaran dan korupsi, sementara Treisman (2000) mengamati tidak ada hubungan yang signifikan antara kedua variabel, karena mungkin untuk ukuran yang berbeda dari korupsi dan dimasukkannya variabel kontrol lebih.

Dalam sebuah studi panel penentu desentralisasi fiskal dalam satu set besar negara untuk tahun 1975, 1980 dan 1985, Panizza (1999) menemukan bukti, bahwa ukuran negara, pendapatan per kapita, tingkat demokrasi, dan, meskipun lemah, fraksionalisasi etnis (sebagai ukuran preferensi heterogen) semua memiliki dampak positif pada tingkat desentralisasi fiskal. De Mello (200) juga berpendapat bahwa fraksionalisasi etno-linguistik mempengaruhi desentralisasi fiskal.

Dalam penelitian terbaru, Jin dan Zou (2002) memberikan tinjauan literatur empiris yang menghasilkan bukti yang bertentangan mengenai hubungan antara ukuran pemerintah dan desentralisasi fiskal. Para peneliti juga memberikan bukti panel bahwa sementara desentralisasi pengeluaran memperbesar ukuran agregat pemerintah, desentralisasi pendapatan memiliki dampak terbalik. Selain itu, dalam kerangka cross-sectional, Raja dan Ma (2001) menyatakan bahwa desentralisasi pendapatan memiliki dampak negatif pada inflasi rata-rata di negara-negara selama 1973-1994. 
Penelitian Hamzah (2007), pada 4 negara muslim, yakni Indonesia, Malaysia, Kazakhstan dan Kyrgystan, menemukan hasil, desentralisasi fiskal secara umum berpengaruh signifikan secara negatif terhadap pertumbuhan ekonomi, artinya desentralisasi fiskal mendorong pertumbuhan ekonomi yanglebih kecil. Secara detail hasil penelitian tersebut menyatakan, desentralisasi pendapatan berpengaruh positif terhadap pertumbuhan ekonomi, desentralisasi pengeluaran dan produksi berpengaruh negatif, capital formation berpengaruh signifikan dan positif, export-import berpengaruh signifikan dan negatif, kredit bank berpengaruh signifikan \& positif dan tingkat inflasi berpengaruh signifikan. Hamzah (2007) juga menekankan pentingnya sistem hukum yang berfungsi dengan baik karena sangat berperan penting pada efektifitas desentralisasi fiskal pada efisiensi alokasi sumber daya dan pertumbuhan ekonomi.

\section{Manfaat dan Kelemahan Desentralisasi Fiskal}

Menurut Bahl (2008), terdapat dua manfaat dan empat kelemahan desentralisasi fiskal. Manfaat desentralisasi fiskal adalah: a) Efisiensi ekonomis. Anggaran daerah untuk pelayanan publik bisa lebih mudah disesuaikan dengan preferensi masyarakat setempat dengan tingkat akuntabilitas dan kemauan bayar yang tinggi; $b$ ) Peluang meningkatkan penerimaan pajak dari pajak daerah.

Pemerintah daerah bisa menarik pajak dengan basis konsumsi dan aset yang tidak bisa ditarik oleh pemerintah Pusat. Sedangkan kelemahannya adalah: a) Lemahnya kontrol pemerintah pusat terhadap ekonomi makro; b) Sulitnya menerapkan kebijakan stabilitas ekonomi; c) Sulitnya menerapkan kebijakan pembangunan ekonomi dengan pemerataan; d) Besarnya biaya yang harus ditanggung pemerintah daerah daripada keuntungan yang didapat.

\section{Tantangan dan Kendala Praktek Kebijakan Desentralisasi Fiskal}

Sudut pandang negatif banyak mengkritik masalah yang timbul dari adanya kebijakan desentralisasi fiskal, seperti konflik yang lebih dalam antara pemerintah daerah, kegagalan pemerintah untuk mengembangkan rencana, atau pemborosan sumber daya bangsa karena tumpang tindih investasi secara umum. Di sisi lain, sudut pandang positif dari pendukung desentralisasi memberikan pendapat, desentralisasi fiskal membuat kontribusi besar untuk kemajuan demokrasi, peningkatan pelayanan publik untuk penduduk, revitalisasi partisipasi antara penduduk dan kelompok warga dan sebagainya. Dengan demikian, hal krusial terletak pada sistem pemerintahan setempat, apakah fokus atau tidak pada kelayakan ekonomi dan efisiensi, dan apakah berfokus pada poinnilai yang berorientasi pada kesetaraan dan demokrasi.

Dalam sudut pandang yang berlawanan, salah satu subyek yang menarik adalah bahwa pemerintah daerah atau kepala daerah rata-rata mengikuti kebijakan pertumbuhan ekonomi pusat. Dengan kata lain, perluasan kesejahteraan sosial dapat menghambat pertumbuhan ekonomi di tingkat regional dan pembangunan daerah berada dalam hubungan mengimbangi. Diasumsikan juga bahwa politisi dan pejabat setempat lebih memilih kebijakan ekonomi untuk menghindari penurunan rating atau elektibilitas mereka (Pauly, 1973; Peterson, 1981; King, 1984; Kernell, 1986; Schneider, 1989; Kang, 2001; Jin 2005 re-kutipan). 
Ekonomika-Bisnis Vol. 4 No.1 Bulan Januari Tahun 2013. Hal 1-12

Perhatian utama dari kepala pemerintah daerah atau anggota dewan kota adalah untuk memenangkan pemilu lokal dan itu sangat penting untuk memiliki dukungan politik. Oleh karenaitu, penguatan kebijakan kesejahteraan sosial dapat diberikan sebagai sarana utama untuk mendapatkan sentralisasi kekuasaan dan untuk memenangkan pemilihan. Itu adalah pilihan politisi lokal menjadi rasionalis politik sebelum menjadi rasionalis ekonomi (Fry \& Musim Dingin, 1970; Byole \& Jacob, 1982; Wong, 1988; Kim, 1998; Lee, 2000; Kim, 2000; Kang, 2001; Jin 2005 re-kutipan).

Penjelasan fenomena umum atas tantangan, kelemahan dan kelebihan dari praktek desentralisasi fiskal tersebut di atas secara umum ditemukan di banyak negara yang akan dikaji dalam tulisan ini.

\section{Gambaran Umum Tren Desentralisasi}

Untuk semua jenis kebijakan desentralisasi, kita mengamati bahwa negara maju memiliki desentralisasi jauh lebih tinggi daripada negara-negara kurang berkembang.Dari tahun 1970-an sampai akhir 1990-an, Kanada, Swiss, Australia dan Amerika Serikat, dalam urutan, peringkat di antara yang paling terdesentralisasi (sehubungan dengan pengeluaran fiskal) negara, diikuti oleh Argentina, India, Pakistan dan Brasil dari kelompok negara berkembang. Diantara negara-negara maju, Austria, Swiss, Amerika Serikat memiliki desentralisasi pengeluaran yang kurang sejak 1970-an, sedangkan Spanyol dan Jerman memiliki pengeluaran lebih terdesentralisasi selama dekade terakhir. Di

Tabel 1. Tax Allocations Among Levels of Government

\begin{tabular}{lccc}
\hline \multicolumn{1}{c}{ Country } & Federal & Region/State & Local \\
\hline Brazil & 45.6 & 47.4 & 7.0 \\
China & 52.1 & $47.9^{*}$ & \\
Germany & 50.2 & 37.4 & 12.4 \\
India & 46.6 & $53.4^{*}$ & \\
Japan & 60.0 & $40.0^{*}$ & \\
Korea & 79.0 & $21.0^{*}$ & \\
Russia & 46.3 & $53.7^{*}$ & \\
United States & 59.5 & 25.3 & 15.2 \\
\hline
\end{tabular}

* Local tax revenues are included in the state totals

Source: Financial documents from the various countries for FY 1997 or 1998; see references

Tabel 2. Model Tax Allocation Sistem

\begin{tabular}{ll}
\hline Central Government & \multicolumn{1}{c}{ Regional/Local Government } \\
\hline --Income Taxes & --Property Taxes \\
--Import and Export Duties & --Business Taxes \\
--Charges and Fees & \\
Shared/Joint Taxes & --Gaming/lottery \\
--Natural Resource Taxes & \\
national tax) & --Income or VAT (piggybacked on \\
--VAT --Excise Taxes &
\end{tabular}

Sumber: James Edwin Kee, Professor of Public Policy and Public Administration, The George Washington University 
antara negara-negara kurang berkembang, Argentina juga telah melaksanakan desentralisasi pengeluaran terkenal sejak 1970an, sementara Bolivia, Malaysia dan Peru memiliki kecenderungan sebaliknya. Di bawah ini terdapat beberapa tabel yang menggambarkan tren desentralisasi fiskal di berbagai negara.

\section{Kebijakan Publik Islam}

Dalam negara Islamkebijakan fiskal merupakan salah satu dari berbagai alat yang bekerja untuk mencapai tujuan Syariah. Secara teknis, seperti negaranegara lain, negara Islam juga memiliki tanggung jawab untuk menjaga hukum dan ketertiban dan untuk menyediakan infrastruktur yang dibutuhkan untuk mendorong pertumbuhan ekonomi. Negara dalam perspektif Islam juga harus aktif dalam mengurangi kesenjangan pendapatandan kekayaan dan mempromosikan tatanan ekonomi dan sosial yang egaliter.

Dalam beberapa tahun terakhir kebijakan fiskal telah memainkan peran penting dalam menstabilkanekonomi Barat, ter- utama setelah terjadinya depresi besar. Dalam perekonomian di mana kapasitas produktif dikembangkan dengan baik, kebijakan fiskal dapat memainkanperan penting dalam mengatur permintaan agregat. Di negara-negara tersebut, dikembangkan sistem kesejahteraan pajak dan kebijakan fiskal sosialuntuk bekerja secara fleksibel dalam memerangïnflasi atau deflasi. Dalam negara Islam stabilitas perekonomian dianggap wajib. Salah satu contoh adalah pada kasus Inflasi dapat membahayakan kesejahteraan masyarakat dan menghasilkan distribusi pendapatan dan kekayaan yang terpusat di tangan si kaya saja. Kondisi deflasi juga berbahaya. Ibn Khaldun mengamati lama bahwa jika Negara tidak memperhatikan arus keuangan kepada publik, ini akan menghasilkan resesi. Kelancaran arus uang menjadi penting untukmencegah penurunan permintaan agregat dan supply. Kebijakan fiskal untuk mengurangi agregat dan meningkatkan produktivitas akan diperlukan ketika ekonomi berada di bawah kondisi inflasi. Pajak progresif atas penghasilan dan pengeluaran serta jaminan

Tabel 3.Percent Composition of Tax Revenue: China and Brazil

\begin{tabular}{|c|c|c|c|c|c|}
\hline Tax China & & $\begin{array}{l}\text { Central Province } \\
\text { China /Local }\end{array}$ & $\begin{array}{l}\text { Brazil } \\
\text { Union }\end{array}$ & $\begin{array}{l}\text { Brazil } \\
\text { State/Local }\end{array}$ & \\
\hline $\begin{array}{l}\text { PI Tax } \\
\text { (Personal Income) }\end{array}$ & & 19.9 & & 15.8 & 10.5 \\
\hline Business IT & 8.2 & 3.1 & & & \\
\hline Other Business & 4.9 & 41.1 & 2.1 & & \\
\hline Consumption:VAT & 56.2 & 20.8 & 11.5 & 76.5 & \\
\hline Cons: Sales & 16.9 & & & & \\
\hline $\begin{array}{l}\text { Cons: Services } \\
\text { Customs/Duties }\end{array}$ & 8.9 & & 3.9 & 1.6 & \\
\hline Prop/Land/Agr & & 9.8 & .1 & 1.6 & \\
\hline $\begin{array}{l}\text { Sosial } \\
\text { Contributions }\end{array}$ & & & & 52.9 & 6.8 \\
\hline Miscellaneous & 5.0 & 5.313 .7 & & 3.0 & \\
\hline
\end{tabular}

Sources: Finance Ministries of China and Brazil and calculations by the author. 
sosial pembayaran dapat bertindak sebagai stabilisator otomatis bagi perekonomian.

Kebijakan fiskaldalam negara Islam tidak harus menjadi faktor penghambat. Ibn Khaldun memperingatkan terhadap kemungkinan efek samping dari pajak yang berlebihan pada keinginan untuk berinvestasi danselanjutnya bisa menghambat pertumbuhan ekonomi.Unsur-unsur utama dari teori fiskal Islam iniadalah: 1) Ekonomi Islam terdiri dari ekonomi tiga sektor, yaitu, sektor swasta, sektor sosial/sukarela, dan sektor publik. Tiga sektor bekerja sama, memberikan kerangka kelembagaanpada perekonomian Islam; 2) Zakat sebagai dasar dari sistem fiskal; 3) Alokasi, distribusi danfungsi stabilisasi dari ekonomi Islam diproses dan dilaksanakan melaluisemua sektortersebut secara bersama-sama; 4) Peran sektor publikdibanding sektor lain adalah minimal tapi penting sejauh beroperasi terusmenerus untuk memastikan

Tabel 4. Penerimaan Negara Masa Khulafaur Rasyidin

\begin{tabular}{|c|c|c|c|c|c|}
\hline No & \multicolumn{3}{|c|}{ Jenis Penerimaan } & Sumber & $\begin{array}{c}\text { Diterapkan } \\
\text { sejak }\end{array}$ \\
\hline 1 & \multicolumn{3}{|c|}{$\begin{array}{l}\text { Zakat Dikeluarkan kepada } 8 \text { Asnaf } \\
\text { Zakat }\end{array}$} & $\begin{array}{l}\text { Harta kaum muslimin, seperti unta, } \\
\text { kambing, sapi, dinar, dirham \& } \\
\text { hasil bumi besarnya sesuai nisab } \\
\text { yang telah diatur syariah }\end{array}$ & $\begin{array}{l}\text { Rasulullah } \\
\text { Muhammad } \\
\text { Saw }\end{array}$ \\
\hline \multirow[t]{3}{*}{2} & \multirow{3}{*}{$\begin{array}{l}\text { Pungutan/ } \\
\text { premiyang } \\
\text { digunakan untuk } \\
\text { membayar pasukan } \\
\text { perang \& } \\
\text { kemaslahatan kaum } \\
\text { muslimin yang } \\
\text { diatur oleh } \\
\text { pemerintah pusat }\end{array}$} & 1 & Kharaj & $\begin{array}{l}\text { Tanah yg dikuasai pasukan } \\
\text { muslimin dan dibiarkan di tangan } \\
\text { mereka }\end{array}$ & $\begin{array}{l}\text { Umar Bin } \\
\text { Khatab }\end{array}$ \\
\hline & & 2 & Usyur & $\begin{array}{l}\text { 1/10 hasil bumi yg diserahkan } \\
\text { pemiliknya dr wil Arab/luar Arab }\end{array}$ & $\begin{array}{l}\text { Umar Bin } \\
\text { Khatab }\end{array}$ \\
\hline & & \multirow[t]{3}{*}{3} & \multirow[t]{2}{*}{ Jizyah } & $\begin{array}{l}\text { Upeti yg harus dibayar kafir } \\
\text { dzimmi lelaki sebagai pengganti } \\
\text { perlindunganyg diberikan kepada } \\
\text { meraka dr bahaya serangan musuh, } \\
12 \text { dirham< jizyah< } 48 \text { dirham } \\
\text { (tidak berlaku bagi wanita, anak- } \\
\text { anak, orang miskin/ tidak bisa } \\
\text { bekerja) }\end{array}$ & $\begin{array}{l}\text { Umar Bin } \\
\text { Khatab }\end{array}$ \\
\hline 3 & Pajak & & & $\begin{array}{l}\text { 1/10 dari harta dagangan } \\
\text { kaum muslimin yang } \\
\text { berdagang di luar wilayah } \\
\text { Islam } \\
\text { - } 1 / 40 \text { utk kafir dzimmi } \\
1 \text { dirham utk tiap } 40 \text { dirham } \\
\text { untuk kaum muslimin, tetapi } \\
\text { di bawah } 200 \text { dirham tidak } \\
\text { dipungut apapun }\end{array}$ & $\begin{array}{l}\text { Umar Bin } \\
\text { Khatab }\end{array}$ \\
\hline 4 & Rampasan Perang & & & $\begin{array}{l}\text { - } \quad 4 / 5 \text { untuk orang yg } \\
\text { mendapatkan } \\
\text { - } \quad 1 / 5 \text { untuk Baitul Maal }\end{array}$ & \\
\hline
\end{tabular}

Sumber:Atlas Sejarah Islam Masa Permulaan Hingga Kejayaan Islam (2011) 
alokasi optimal sumber daya yang ada dalam masyarakat, distribusi pendapatan, dan membangun stabilitas.

Fungsi alokasi ekonomi Islam juga memerlukan rancangan sistem pajak, untuk optimalisasi alokasi sumber daya masyarakat antara berbagai sektor ekonomi. Kebijakan pajak bersama-sama dengan kebijakan moneter dan langkah-langkah pengaturan lainnya. Pandangan pemikir Islam seperti Imam Malik, Ibnu Hazm dan Kattani bahwa kebijakan fiskal Islam diluar zakat adalah sistempajak. Sistem pajak dibenarkan hanya untuk memenuhi kebutuhan pertahanan, jaminan untuk kebutuhan minimal orang miskin, biaya yang sangat diperlukan yang melindungi kepentingan kolektif umat Islam, dan juga penggunaan perpajakan untuk tujuan purpose redistribusi pendapatan. Di era pemerintahan Islam saat ini perpajakan dibenarkan bagi promosi tatanan egaliter sosio-ekonomi, percepatan pertumbuhan ekonomidan pemeliharaan stabilitas moneter. Namun untuk menjaga perpajakan dalam batas yang wajar,semua pengeluaran boros harus dihindari dan pengeluaran administrasiharus ditekan ke tingkat yang minimum.
Khusus untuk zakat sebagai sentral instrumen fiskal Islam, Metwally (1983) menemukan bahwa pengeluaran zakat memiliki kemampuan untukmeningkatkan konsumsi agregat karena marginal propensity to consumpt dari pembayar zakat lebih rendah dibandingkan dengan penerima zakat.Ini berarti bahwa pengeluaran zakat memiliki peran dalam pendapatan nasional, semakin tinggi pengeluaran zakat semakin tinggi kenaikandalam output ekuilibrium.

\section{Bukti Sejarah Kejayaan Ekonomi Pada Masa Khilafah Islamiyah}

Berikut ini akan dijelaskan beberapa contoh realita sejarah tentang kejayaan ekonomi pada masa Khilafah Islamiyah, yang bisa dijadikan studi banding untuk merumuskan kebijakan fiskal ideal di era modern saat ini.

Masa Khalifah Umar bin Khaththab selama 10 tahun, di berbagai provinsi yang menerapkan Islam dengan baik, kaum muslimin dan juga golongan non muslimmenikmati kemakmuran \& kesejahteraan yang merata. Sebagai salah satu contoh kasus, pada tahun kedua, Muadz mengirimkan separuh hasil zakat yang dipungutnya

Tabel 5. Sumber-Sumber Pendapatan Pada Masa Rasulullah SAW

\begin{tabular}{lll}
\hline \multicolumn{1}{c}{ Dari Kaum Muslimin } & Dari Kaum Non Muslim & \multicolumn{1}{c}{ Umum } \\
\hline 1.Zakat & 1.Jizyah & 1.Ghanimah \\
2.Ushr $(5-10 \%)$ & 2.Kharaj & 2.Fay \\
3.Ushr $(2,5 \%)$ & 3.Ushr $(5 \%)$ & 3.Uang Tebusan \\
4.Zakat Fitrah & & 4.Pinjaman dari kaum \\
& & muslim atau non muslim \\
5.Wakaf & 5.Hadiah dari pemimpin atau \\
& pemerintah negara lain \\
6.Amwal Fadhla & \\
7.Nawaib & \\
8.Shadaqah yang lain & \\
9.Khumus & \\
\hline
\end{tabular}

Sumber: Sabzawari 1984 
kepada Umar, tetapi Umar mengembalikannya. Pada tahun ketiga, Muadz mengirimkan semua hasil zakat yang dipungutnya, yang juga dikembalikan Umar. Muadz berkata," Saya tidak menjumpai seorang pun yang berhak menerima bagian zakat yang saya pungut." (Al Qaradhawi, 1995).Meski rakyatnya sejahtera, Umar tetap hidup sederhana, hanya mendapat tunjangan dari Baitul Maal sebesar 16.000 dirham (setara Rp 200 juta) per tahun, atau hanya sekitar Rp17 juta per bulan (Muhammad, 2002).

Masa Khalifah Umar bin Abdul Aziz, meskipun masa kekhalifahannya cukup singkat, hanya sekitar 3 tahun (99-102 H/ 818-820 M), namun prestasinya akan selalu dikenang umat Islam, sebagai Khalifah yang berhasil mensejahterakan rakyat. Ibd Abdil Hakam dalam kitabnya Sirah Umar bin AbdulAziz hal.59 meriwayatkan, Yahya bin Said, seorang petugas zakat masa itu berkata," Saya pernah diutus Umar bin Abdul Aziz untuk memungut zakat diAfrika. Setelah memungutnya saya bermaksud memberikannya kepada orang-orang miskin. Namun saya tidak menjumpai seorang pun. Umar Bin AbdulAziz telah menjadikan semua rakyat pada waktu itu berkecukupan. Akhirnya saya memutuskan untuk membeli budak lalu memerdekakannya." (Al Qaradhawi, 1995).

Terlepas dari adanya kekurangan dan kelebihan pada masing-masing sektor dalam proses bernegara, bagaimanapun kesuksesan ekonomi yang dicapai pada masa khalifah pemerintahan Islam layak menjadi rujukan. Hal tersebut juga dinyatakan oleh sejarawan barat, Montgomerry Watt (1972), "Cukup beralasan jika kita menyatakan bahwa peradaban Eropa tidak dibangun oleh proses regenerasi mereka sendiri. Tanpa dukungan peradaban Islam yang menjadi dinamonya, Barat bukanlah apa-apa."”

\section{Penutup}

Pertama, hasil pembahasan dan analisa menunjukkan bahwafaktor-faktor yang berkaitan dengan efektifitas desentralisasi fiskal kontemporer yang dipraktekkan banyak negara saat ini sebagai berikut: a) Desentralisasi fiskal terkait erat dengan efisiensi dinamika ekonomi, khususnya pembangunan ekonomi; b) Desentralisasi akan lebih mampu menyukseskan tujuan-tujuan pembangunan lewat pemberian hak kontrol kepada masyarakat yang memiliki informasi dan insentif untuk membuat keputusan yang sesuai dengan kebutuhan mereka; c) Modal sosial yang lebih tinggi, yang didefinisikan sebagai kepercayaan pada pemerintah, kerjasama sipil dan aktivitas asosiasi, berhubungan positif dengan desentralisasi fiskal, terutama bila diukur oleh ketidakseimbangan vertical; d) Secara umum, efektivitas desentralisasi fiskal tergantung pada faktor-faktor seperti ukuran negara, tingkat privatisasi dalam perekonomian, kemampuan pemerintah daerah untuk meningkatkan pendapatan, transparansi dankapasitas administrasi dan kelembagaan lokal; e) Desentralisasi fiskal dapat memberikan kontribusi besar untuk kemajuan demokrasi, peningkatan pelayanan publik untuk penduduk, revitalisasi partisipasi antara penduduk dan kelompok warga dan sebagainya, namun sudut pandang negatif banyak mengkritik masalah yang timbul dari adanya kebijakan desentralisasi fiskal, seperti konflik yang lebih dalam antara pemerintah daerah, kegagalan pemerintah untuk mengembangkan rencana, atau pemborosan sumber daya bangsa karena tumpang tindih investasi secara umum; f) Secara umum,terdapat hasil penelitian yang berbeda-beda di berbagai negara antara hubungan desentralisasi fiskal, indikator makro dan pertumbuhan ekonomi; g) Untuk mendukung efektifitas 
desentralisasi fiskal dan menekan kelemahannya, mutlak diperlukan sistem hukum yang berfungsi dengan baik

Kedua, Kebijakan publik Islam memiliki poin-poin sebagai berikut: a) Islam memiliki 3 sektor ekonomi yakni sektor sosial, swasta dan publik; b)Kebijakan fiskal terpusat pada instrumen zakat, dan sistem perpajakan dengan syarat yang sangat ketat agar tidak menimbulkan gangguan pada perekonomian, membebani dunia usaha dan masyarakat; c) Penerapan semua instrumen tersebut melarang adanya eksploitasi yang menyebabkan riba, gharar/ketidakpastian, spekulasi, produk dan jasa yang diharamkan dan semua bentuk kezaliman.

Ketiga, Kebijakan desentralisasi fiskal yang dijalankan pada era modern saat ini, minus zakat dan instrumen sosial Islam lainnya, yakni infak, shadaqah dan wakaf, memiliki kerangka tujuan yang sejalan dengan perspektif ekonomi Islam, namun penyimpangan pada implementasi masih banyak, yang diindikasikan karena masih banyaknya muatan eksploitasi sebagaimana yang dilarang dalam Islam.

\section{DAFTAR PUSTAKA}

Baltagi, B., 1995.Econometric Analysis of Panel Data. John Wiley and SonsLtd

Barrett, BFD. 2000.Decentralization in Japan: Negotiating the transfer Authority. Japanese Studies, Vol. 20, 1.

Blanchard, O. and Shleifer, A. 2000.Federalism with and without Political

Centralization: China versus Russia National Bureau Of Economic Research Working Paper Series(U.S.), March 7616:1-14 No...

Bradhan, P., and D. Mookherjee. 1998.Expenditure Decentralization and
Provision of Public Services in Developing Countries. Sari Convention Working Paper, No. 98-104 (Berkeley, California: International Center for Research and Economic Development).

Cukierman, A., S. And B. Webb, Neyapti. 1992.Measuring Independence

Central Banks and Its Effect on Policy Outcomes. World BankEconomic Review, 6, 353-98 September.

Bilin Neyapti. 2003.Fiscal Decentralization and Macroeconomic Performance: International Evidence. Bilkent University, Ankara, Turkey in January, 2003

Davoodi, HR. 1998.FiscalDecentralization and Economic Growth: ACross-

Country Study.Journal of Urban Economics (USA), 43, pp.244-257.

De Mello, L., 2000.Can Fiscal Decentralization Strengthening Social Capital?.IMF Working Paper, WP/00/129.

De Mello. 2000.Fiscal Decentralization and IntergovernmentalFiscal

Relationships: A Cross-Country Analysis. World Development, $\mathrm{Vol} 28$, No. 2, pp. 365-380..

Donahue. 1997.Tiebout Tiebout or Not? Market Metaphor and America

Devolution debate.Journal of Economic Perspectives, Vol. 11, No. 4, pp.7381.

Eaton, K. 2001.Barriers to Political Decentralization: Evidence fromArgentina and the Philippines.Development and Change, Vol. 32, pp. 101-27.

Fisman, R. and R. Gatti. 2002.Decentralization and Corruption: Evidence Across 
Ekonomika-Bisnis Vol. 4 No.1 Bulan Januari Tahun 2013. Hal 1-12

Countries.Journal of Public Economics 83, pp. 325-545.

Haussmann, J. 1979.Specification Tests in Econometrics.Econometrica, Vol. 46, pp. 1251-1271.

Hope, KR.2000.Decentralization and Local Governance in Theory and Practice Botswana.Development Southern Africa, Vol. 17, No. 4, October.

Im, Dong-Wook andJung, Jae-Jin. 2005. Studies onthe effectiveness offiscal decentralizationpolicy Participatory Government: focusonlocalallocation taxrate increasesandlocalconsumption taxes. The study ofthe Korean Societyand Public Administration, 16(2):139-161

Inman, RP and DLRubinfield. 1997.Rethinking Federalism, Journal of

Economic Perspectives, Vol. 11, No. 4, pp.43-64.

Jin, Jae-Moon. 2005. The relationship betweenlocal electionsandlocal governmentpolicy orientation: orientationorientationwelfareorcommunity development. The study oflocal financialKorea, 10(2):5-26.

June, Sang-kyung. 1999. The Political Economy ofLocal Government Financial Management Autonomous Region. The study oflocal government, 6(3): 109-129.

KimTae-il. 2001. Regional Autonomyand Local GovernmentSpending Welfare. KoreanPublic AdministrationStudies, 35(1).

KoreanLiterature, Choe, Byeong-ho andJeong, Jong-Peel. 2001. AStudyon the RelationshipbetweenFiscal Decentralizationand Regional Eco- nomic GrowthinKorea. The study oflocal financialKorea, 6(2) 177202.

KwonO-sung. 2004. ElectedLocal Government ImpactonFiscal Decentralization: An EmpiricalTestinthe City59. KoreanPublic AdministrationStudies, 38(1).

Lee, Seung-Jong. 2001. Regional AutonomyandLocal Government Orientalized Welfare Policy. KoreanPublic AdministrationStudies, 34(4).

Sohn, Hee-June. 2005. Evaluation ofFiscal DecentralizationPolicyinKorea. The study ofGeovernanceKorea, 12(2):159-185.

Muhammad Zilal Hamzah. 2007. FiscalDecentralization and Economic Growth: Evidence of Some Empirical Research. Indonesian Business School.Jakarta.

Panizza, U. 1999. On the Determinants of FiscalCentralization: Theory and

Evidence.Journal of Public Economics 74, pp. 97-139.

Samuelson, Paul A. 1954. Pure Theory of Public Expenditure.Review

Economics and Statistics, Vol. 36, No. 4, November, 387-389.

Ziauddin Ahmed, Munawar Iqbal, M. Fahim Khan. 1983.Fiskal Policy and Resource Allocation in Islam. International Centre for Research in Islamic Economics, King Abdulaziz University, Jeddah And Institute of Policy Studies, Islamabad, Digital Composition for Web by: Syed Anwer Mahmood Islamic Economics Research Centre Published on Net May 2008 